proaches censure of Roosevelt came when Wallace, after listening to discussions of the Palestine question, observed: "The President certainly is a waterman. He looks one direction and rows the other with utmost skill." (p. 313) On the other hand, from the beginning, Wallace had doubts about Truman's ability to handle the awesome responsibilities of the Presidency. Because he was so often involved in decision-making at the highest levels, Wallace's diary illuminates one of the most critical periods in American history. While it will be of greatest use for recent American historians, the non-professional will find rewarding reading in this diary of one of Iowa's most famous sons.

Peter L. Petersen

West Texas State University

\title{
\# \#
}

Demise of the Democracy: The Copperhead Press in Iowa, by David L. Lendt. Ames: The Iowa State University Press, Replica Edition. 1973.

David L. Lendt's study of the Copperhead press in Iowa during the Civil War era is one of mixed quality. Over-all, he cogently argues that the state's Republican majority persecuted the Copperhead press for political purposes. He demonstrates that these anti-Lincoln, anti-war newspapers were not only a manifestation of pro-Southern sentiment; rather, they served also as forums for immigrants and social, economic and political conservatives. Lendt further suggests that Iowa's Copperhead editors came mainly from the ranks of the state's Democratic newspapermen who saw themselves as the "loyal opposition." These editors advocated neither violence nor lawlessness and at no time politically threatened Iowa's pro-Union stance. 
The Lendt book has numerous shortcomings. At times it is more a study of a few Copperhead papers than an analysis of the press as a whole. Moreover, the author frequently fails to use either the best or latest monographic literature. Instead he often turns to a college-level textbook, The United States, by Hofstadter, Miller and Aaron, even using the 1957 edition! Errors and confusing statements mar the text. For instance, he writes on page 99 that editor Henry Clay Dean "was a Methodist preacher and Chaplain in the U.S. Senate during part of Pierce's administration. [1853-1857] When the Methodist Episcopal Church split on the question of slavery in 1844 , he retired from the ministry and returned to law." The latter sentence, of course, seemingly contradicts the former one.

Demise of the Democracy: The Copperhead Press in Iowa is a photo-offset reduction of Lendt's original typescript. Although this concept of publishing is excellent, bringing into general circulation studies that might forever be lost, in Lendt's case it merely reinforces this reviewer's impression that the end product is still an unedited master's thesis. Considering the limitations of Lendt's work, it might have paid him to condense his essential points in an article-length piece on the Copperhead press as he did with "Iowa and the Copperhead Movement" for the Fall 1970 issue of the Annals of Iowa.

\section{-H. Roger Grant} The University of Akron

Mine, by Ransom Jeffery and John Keeble. New York: Grossman Publishers Inc. 1974. pp. 280. \$7.95.

There is a new and unorthodox Iowa in Ransom Jeffery and John Keeble's recent collaborative novel. Gone is the Iowa of farmers struggling with the land, of settlers fighting the weather. 
Copyright of Annals of Iowa is the property of State of Iowa, by \& through the State Historical Society of Iowa and its content may not be copied or emailed to multiple sites or posted to a listserv without the copyright holder's express written permission. However, users may print, download, or email articles for individual use. 